\title{
KORELASI ANTARA SELF-COMPASSION DENGAN KECEMASAN SOSIAL PADA ANAK USIA SEKOLAH DASAR DI KOTA BANDUNG
}

\author{
Lucia Voni Pebriani dan Puspita Adhi Kusuma W. \\ Fakultas Psikologi Universitas Padjadjaran \\ J1. Raya Bandung-Sumedang KM.21 Jatinangor, Sumedang, Jawa Barat \\ Email: lucia.voni@unpad.ac.id
}

\begin{abstract}
ABSTRAK
Kecemasan sosial adalah perasaan dan pengalaman kognitif yang muncul karena adanya persepsi bahwa seorang individu dievaluasi negatif oleh orang lain. Persepsi tersebut membuat individu menjadi sensitif terhadap kritik orang lain dan juga sering mengkritik diri secara negatif saat mengalami kegagalan. Perilaku evaluasi diri negatif dan mengkritik diri sendiri juga merupakan ciri self-compassion yang rendah. Self-compassion adalah keadaan menerima kegagalan dengan tetap memperlakukan diri sendiri dengan baik, memahami diri sendiri dengan tidak memberikan penilaian negatif pada ketidaksempurnaan diri, dan memandang pengalaman negatif yang dialami sebagai pengalaman yang umum terjadi. Penelitian ini dilakukan mengingat belum terdapat penelitian yang menghubungkan kecemasan sosial dengan self-compassion, khususnya pada anak sekolah dasar (8-12 tahun), dimana kecemasan sosial sudah dapat ditetapkan diagnosisnya pada usia tersebut. Pemilihan responden menggunakan metode cluster random sampling, dengan karakteristiknya adalah anak usia 8-12 tahun di Kota Bandung, jumlah responden 403 orang (laki-laki $=41,9 \%$, perempuan $=58,15 \%$ ). Alat ukur yang digunakan adalah Self-compassion Scale (SCS) dan Liebowitz Social Anxiety Scale for Children (LSAS-C). Hasil uji reliabilitas untuk LSAS-C, adalah 0,911 dan SCS adalah 0,871. Analisis statistika korelasi dilakukan dengan menggunakan korelasi Pearson. Hasil dari uji korelasi menunjukkan adanya korelasi negatif antara self-compassion dan kecemasan sosial $(r=-0,025)$. Semakin rendah self-compassion maka semakin tinggi kecemasan sosial.
\end{abstract}

Kata kunci: kecemasan sosial; self-compassion; anak usia sekolah dasar; Bandung

\section{CORRELATION BETWEEN SELF-COMPASSION WITH SOCIAL ANXIETY IN ELEMENTARY SCHOOL AGE CHILDREN IN BANDUNG}

\begin{abstract}
Social anxiety is a feeling and cognitive experience that arises because the perception of someone being negatively evaluated by others, which makes a person become sensitive to the criticisms from the others. Some studies also state that children who experience social anxiety are also often criticize themselves negatively when they failed. Negative self evaluation and self-criticism behaviors are also characteristics of the low self-compassion. Selfcompassion is a state of accepting failure that one is experienced whilst still treating oneself well, practicing a sense of understanding of oneself, and perceiving negative experiences as a common. There were no studies linking social anxiety with self-compassion, especially in elementary school children (8-12 years), where social anxiety could be diagnosed at that age. Clustered random sampling was used for the respondents selection, with the characteristics of children aged 8-12 years in Bandung, the number of respondents was 403 people (male $=41.9 \%$, female $=58.15 \%$ ). The instruments were used for data collection were the Self-compassion Scale (SCS) and the Liebowitz sosial Anxiety Scale for Children (LSAS-C). The reliability test results for LSAS-C, are 0.911 and SCS is 0.871 . Analysis of correlation was performed using Pearson correlation. Result showed that there was a negative correlation between self-compassion and social anxiety $(r=-0,025)$. Result indicated that the lower self-compassion children got, the higher social anxiety they perceived.
\end{abstract}

Keyword: social anxiety; self-compassion; elementary school; children; Bandung 


\section{PENDAHULUAN}

Masa anak-anak usia sekolah dasar merupakan periode ketika anak banyak melakukan interaksi dengan teman sebaya dibandingkan dengan ketika masa prasekolah. Menurut Santrock (2004), anak-anak berinteraksi dengan teman-teman sebaya $10 \%$ dari waktu siang mereka pada usia 2 tahun, $20 \%$ pada usia 4 tahun, dan lebih dari 40\% antara usia 7 tahun dan 12 tahun (Barker \& Wright dalam Santrock 2004). Dalam berinteraksi dengan teman-teman sebaya, setiap anak mempunyai perasaan dan kondisi yang berbeda-beda. Ada anak yang sangat senang dan menikmati ketika bermain dengan teman-temannya, ada yang pemalu, dan ada juga yang sedikit ketakutan atau khawatir. Rasa khawatir ketika berada dalam situasi sosial yang baru merupakan pengalaman yang dialami oleh beberapa anak. Tuntutan sosial yang menekan anak untuk terlibat dalam situasi sosial, yaitu berinteraksi dengan teman sebayanya maupun orang dewasa lainnya, dapat menimbulkan masalah, mengganggu, dan menakutkan bagi anak-anak tertentu." (Kearney, 2005). Anak-anak tersebut merasa tidak nyaman ketika berada dalam situasi sosial.

Anak yang mengalami ketidaknyamanan ketika berinteraksi dengan anak lain atau dengan orang dewasa mungkin mengalami kecemasan sosial (American Psychiatric Association, 2000). Meskipun mereka dapat berinteraksi dengan anak lain, mereka pada umumnya mencoba untuk menghindari situasi sosial yang mengharuskan mereka untuk tampil dan dinilai (Silverman \& Ginsburg, 1998). Kecemasan sosial adalah pengalaman kognitif dan perasaan yang muncul karena adanya persepsi bahwa dirinya dievaluasi negatif oleh orang lain (Schlenker \& Leary, 1982). Individu yang mengalami kecemasan sosial adalah individu yang berlebihan dalam memandang evaluasi atau kritik mengenai dirinya sendiri dari orang lain. Hal ini muncul dalam ketakutan dan menghindar dalam situasi sosial yang dapat menyebabkan kesulitan dalam melaksanakan fungsi hidup sehari-hari (Henderson \& Zimbardo, 2010).

Dampak dari kecemasan sosial yang seringkali dialami anak-anak tidaklah ringan. Anak-anak yang mengalami kecemasan sosial seringkali berkaitan dengan dukungan sosial yang lebih rendah, hubungan sosial yang tertutup, perasaan negatif yang lebih tinggi serta perasaan pesimis sosial yang lebih besar (Kashdan \& Herbert, 2001). Pada remaja, mereka cenderung mempunyai jaringan sosial yang lebih sedikit, prestasi akademik yang lebih rendah dibandingkan kemampuan sebenarnya, dan mempunyai penyesuaian diri yang lebih rendah (Masia-Wrnerm Storch, Fisher \& Klein, 2003). Tidak hanya itu, dampak dari kecemasan sosial juga seringkali dihubungkan dengan risiko mengalami depresi, memiliki ide untuk bunuh diri, dan menggunakan alkohol maupun obat-obatan. Ketika berlanjut hingga dewasa, social anxiety disorder (gangguan kecemasan sosial) dianggap sebagai gangguan kronis yang tidak berhenti dengan probabilitas pemulihan terendah di antara gangguan kecemasan (Bruce et al, 2005).

Banyak faktor dalam diri individu yang dapat menjadi faktor proteksi terhadap kecemasan sosial, salah satunya adalah self-compassion. Self-compassion dipandang sebagai konstruksi penting dalam kesehatan mental (Gilbert, 2014; Neff, 2003a). Self-compassion adalah keadaan menerima dan menanggap kegagalan yang dialami dengan tetap memperlakukan diri sendiri dengan baik, menerapkan rasa memahami pada diri sendiri dengan tidak memberikan penilaian negatif pada ketidakmampuan diri, dan memandang pengalaman negatif yang dialami sebagai pengalaman orang pada umumnya (Neff, 2003). Self-compassion memungkinkan orang untuk peduli dan memaklumi diri sendiri ketika berada pada saat-saat yang sulit dalam hidupnya dan memberikan dirinya sendiri kehangatan dan kenyamanan (Neff, 2010; Wei et al., 2011). Self-compassion dianggap sebagai penyangga terhadap tekanan-tekanan psikologis, termasuk kecemasan sosial. Werner et al. (2012) melaporkan bahwa orang dewasa dengan diagnosis kecemasan sosial mempunyai social compassion yang lebih rendah daripada kelompok kontrol yang tidak memiliki kecemasan sosial.

Beberapa penelitian membuktikkan bahwa self-compassion berhubungan dengan sekian faktor dan proses yang berkaitan dengan kecemasan sosial (Gill, Watson, Williams dan Chan, 2018). Salah satu prosesnya adalah ketakutan akan evaluasi negatif dimana individu dengan kecemasan sosial akan percaya bahwa semua orang akan memperhatikan mereka dan menilai mereka secara negatif (Werner et al, 2012). Ketakutan ini cenderung berdasarkan pengalaman masa lampau dan kepercayaannya (Clark \& Wells, 1995) Ketakutan ini secara serius berdampak pada kemampuan individu untuk menanggulangi situasi sehari-hari. Individu dengan self-compassion yang tinggi akan mampu menjaga situasi negatif tersebut dalam perspektif lain dan melakukan evaluasi diri yang lebih akurat sehingga ketakutan akan evaluasi diri 
menjadi lebih rendah daripada individu dengan self-compassion yang rendah (Leary, Tate, Adams, Allen \& Hancock, 2007).

Proses kedua, individu dengan kecemasan sosial terlibat lebih banyak pada self-focused attention, dimana ia akan memonitor proses internal somatic dan kognitif dalam upaya untuk menghilangkan risiko dari evaluasi sosial yang negatif (Spurr \& Stopa, 2002). Proses ini akan mengurangi perhatian pada stimulus eksternal yang berakibat pada tidak terkoneksi perhatiannya dengan lingkungan dan ketergantungan pada informasi internal untuk menyimpulkan bagaimana seseorang muncul (Rappee \& Heimber, 1997). Hal ini kemudian membawa pada pemikiran yang mengkritik diri sendiri, yaitu persepsi bahwa dirinya merupakan sebuah kegagalan. Hal ini diperkuat dengan kurangnya akses akan informasi eksternal sebagai diskonfirmasi (Cox, Fleet, \& Stein, 2004; Padesky, 1997). Sebuah studi menemukan bahwa orang-orang yang mempunyai self-compassion yang lebih tinggi lebih sedikit terlibat pada proses self-focused. Selain itu, self-compassion yang tinggi menjadi prediktor yang lebih kuat untuk social comparison, kesadaran diri publik, dan self rumination daripada harga diri (Neff \& Vonk, 2009). Dengan sedikitnya keterlibatan pada self-focused, individu dengan self-compassion yang tinggi akan memberikan perhatian lebih besar terhadap lingkungan eksternal sehingga mereka lebih akurat dalam melakukan evaluasi diri.

Self-compassion merupakan konstruk baru di psikologi. Neff (2003) menggambarkan selfcompassion sebagai: (1) berbaik hati dan memahami diri sendiri terhadap rasa sakit atau kegagalan, bukan mengkritik diri sendiri secara keras; (2) menerima pengalaman diri sendiri sebagai bagian dari pengalaman manusia pada umumnya daripada menganggap pengalaman tersebut sebagai tindakan isolasi; (3) meletakkan pikiran dan perasaan yang tersakiti secara sadar daripada terlalu melebih-lebihkan pikiran dan perasaan sakit tersebut. Ketika menghadapi penderitaan, ketidaktepatan, atau kegagalan, selfcompassion menawarkan sebuah kehangatan pada diri sendiri dan pemahaman yang tidak menghakimi daripada berfokus pada rasa sakit dan membombardir diri dengan mengkritik diri sendiri. Manfaat dari self-compassion dapat menjadi benteng dari segala bentuk kemungkinan munculnya psikopatologis (Werner, 2012).

Hubungan negatif antara kecemasan social dan self-compassion juga dilaporkan oleh penelitian Gill et al (2018) pada remaja. Hasil penelitinya menyarankan bahwa self-compassion dapat menjadi faktor protektif dalam melawan berbagai pengalaman, perkembangan, dan gejala-gejala kecemasan yang muncul. Secara spesifik, self-compassion yang tinggi mampu mengubah hubungan remaja dengan diri mereka sendiri yang berdampak pada cara mereka mengevaluasi diri sendiri dan orang lain, baik secara nyata maupun dibayangkan. Begitu pula dalam cara mereka mengatasi situasi sosial yang sebenarnya atau yang dibayangkan sehingga akan berdampak pada pengalaman mereka dan kecemasan sosial (Gill et al, 2018). Meningkatkan self-compassion akan membantu para remaja untuk mengevaluasi pandangan atau pendapat orang lain secara seimbang dan bijak sehingga mengurangi kekhawatiran dan ketakutan yang mungkin muncul. Self-compassion juga membantu remaja untuk mengenali dan menerima bahwa kejanggalan dan kemalangan dalam hidup merupakan hal yang biasa terjadi, dan membuat para remaja melawan self-criticism yang berlebihan. Hubungan yang kuat antara self-compassion dan kecemasan sosial mengurangi kecenderungan untuk menunjukkan perilaku yang menjadi prediktor kuat kecemasan sosial, seperti menghakimi, mengisolasi, atau mengidentifikasi secara berlebihan (Gill et al, 2018).

Selain sebagai faktor yang dapat mengurangi kecemasan sosial, beberapa penelitian juga menyatakan bahwa individu dengan self-compassion yang tinggi mengalami psychological well-being yang lebih tinggi, mencakup bahagia, optimis, dan sosial connectedness dibandingkan dengan individu yang memiliki self-compassion yang rendah. Self-compassion menunjukan korelasi negatif dengan kecemasan, depresi, mengkritik diri sendiri, dan neurotik. (Iskender, 2009; Leary et al., 2007; Pauley \& McPherson, 2010; Terry \& Leary, 2011 dalam Iacono, 2018).

Penelitian mengenai hubungan antara self-compassion dan kecemasan sosial pada anak belum pernah dipublikasikan di Indonesia. Hal ini membuat peneliti tertarik untuk melihat hubungan antara selfcompassion dan kecemasan sosial pada anak usia sekolah dasar di Indonesia. Adapun hipotesis dari penelitian ini adalah adanya korelasi negatif antara self-compassion dan kecemasan sosial pada anak-anak usia sekolah dasar. Semakin tinggi self-compassion maka semakin rendah kecemasan sosial yang dirasakan. Selain dua variabel utama, peneliti juga melihat hubungan antara dimensi atau aspek-aspek dalam self-compassion yang berhubungan dengan kecemasan sosial. 


\section{METODE}

Penelitian ini merupakan penelitian kuantitatif dengan pemilihan responden menggunakan metode clustered random sampling. Dari sebanyak 274 SD Negeri di Kota Bandung, didapatkan 5 perwakilan sekolah, dan dari 203 SD Swasta di seluruh Bandung didapatkan 5 perwakilan SD swasta. Karakteristik responden dalam penelitian ini merupakan anak usia 8-12 tahun. Adapun jumlah responden yang diambil sebagai sampel adalah 403 orang (laki-laki $=169$ orang, perempuan $=234$ orang). Responden mengisi informed consent sebagai tanda kesediaan dalam mengikuti penelitian ini. Pengambilan data dilakukan di dalam kelas secara klasikal dengan menggunakan kuesioner, dimana responden penelitian diminta untuk mengisi kuesioner yang diberikan, yaitu Self-compassion Scale (SCS) dan Liebowitz Sosial Anxiety Scale for Children (LSAS-C). Uji reliabilitas terhadap kedua alat ukur tersebut telah dilakukan menggunakan analisis statistik Alpha Cronbach meggunakan SPSS 19.0. Adapun hasil uji reliabilitas untuk LSAS-C adalah 0,911 dan SCS hasil skor reliabilitasnya adalah 0,871.

Kuesioner Self-compassion Scale (SCS) yang digunakan adalah alat ukur yang diadaptasi dari alat ukur Self-compassion Scale (SCS) dari Neff (2003). Kuesioner ini terdiri dari 26 item. Item tersebut dikategorikan ke dalam enam subscale, yaitu self-kindness (nomor item 5, 12, 19, 23, 26), self-judgement (nomor item 1, 8, 11, 16, 21), common humanity (nomor item 3, 7, 10, 15), isolation (nomor item 4, 13, 18, 35), mindfulness (nomor item 9, 14, 17, 22), dan over identification (nomor item 2, 6, 20, 24). Setiap item harus dijawab dengan memilih satu dari 5 jawaban: Selalu, Sering, Kadang-kadang, Jarang, dan Tidak Pernah, dimana pilihan jawaban memiliki skor 5 (selalu), 4 (sering), 3 (kadang-kadang), 2 (jarang), dan 1 (tidak pernah). Skor masing-masing subscale dihitung dengan menghitung rata-rata tanggapan item subscale. Untuk menghitung total nilai self-compassion, kita perlu membalikkan nilai item subscale negatif sebelum menghitung subscale total. Subscale negatif: self-judgement, isolation, dan overidentification (yaitu, $1=5,2=4,3=3,4=2,5=1$ ) kemudian menghitung rata-rata dari keenam ratarata subscale.

Untuk mengukur kecemasan sosial, digunakan alat ukur berupa kuesioner Liebowitz social Anxiety Scale for Children (LSAS-C) dari Liebowitz (2001). Kuesioner Liebowitz social Anxiety Scale for Children (LSAS-Children) ini terdiri dari 24 item (12 item mengenai situasi interaksi sosial dan 12 item mengenai situasi performansi diri). Responden diminta untuk memberikan penilaian akan rasa takutnya dan kecenderungan berperilaku menghindar pada masing-masing situasi. Adapun penilaiannya adalah sebagai berikut: Takut $0=$ Sama sekali tidak, $1=$ Sedikit, $2=$ Agak, $3=$ Sangat; Menghindar $0=$ Tidak pernah, 1=Kadang-kadang, 2=Seringkali, 3=Hampir selalu. Cara pengisiannya adalah dengan memberi tanda silang $(\mathrm{X})$ pada angka yang sesuai. Adapun cara penilaian adalah dengan menjumlahkan angkaangka yang dipilih responden untuk aspek takut dan aspek menghindar.

Seluruh jawaban responden akan diolah menggunakan pengujian statistik korelasi. Uji korelasi dilakukan dengan menggunakan Pearson Correlation dengan bantuan SPSS versi 19.0 untuk melihat korelasi kecemasan sosial dan self-compassion maupun dengan aspek-aspek dari self-compassion, yaitu self-kindness, self-judgement, common humanity, isolation, mindfullness, over identification, selfcoldness, dan self-warmth.

\section{HASIL DAN PEMBAHASAN}

Berdasarkan data yang dikumpulkan, didapatkan hasil mengenai persentase anak yang mengalami kecemasan sosial sebagai berikut:

Tabel 1. Kategori Kecemasan Sosial

\begin{tabular}{lcc}
\hline \multicolumn{1}{c}{$\begin{array}{c}\text { Kategori Kecemasan } \\
\text { Sosial }\end{array}$} & $\sum$ Subyek & \% \\
\hline Tidak Mengalami & 160 & 39.7 \\
Ringan (Mild) & 222 & 55.1
\end{tabular}




\begin{tabular}{lcc} 
Sedang (Moderate) & 0 & 0.0 \\
Berat (Severe) & 21 & 5.2 \\
Total & 403 & 100 \\
\hline
\end{tabular}

Berdasarkan tabel 1 diatas, dapat disimpulkan bahwa sebanyak 39,7\% anak usia sekolah di Kota Bandung tidak mengalami kecemasan sosial, sebanyak 55,1\% siswa usia sekolah di Kota Bandung mengalami kecemasan sosial ringan (mild), dan sebanyak 5,2\% mengalami kecemasan sosial berat (severe), serta tidak terdapat ( $0 \%$ ) siswa yang mengalami kecemasan sosial kategori sedang (moderate). Hasil ini menunjukan bahwa sebagian besar siswa usia sekolah dasar di Kota Bandung masih dapat menjalankan kegiatan interaksi dengan orang-orang yang mereka temui di sekolah serta area sosial lainnya dan merasa cemas hanya pada situasi tertentu. Mereka memiliki keinginan untuk masuk pada situasi sosial tertentu, tetapi terkadang mereka memilih untuk tidak mencoba karena rasa cemas yang dimiliki.

Sementara itu, hasil persentase kategori Self-compassion dari anak usia sekolah dasar di Kota Bandung adalah sebagai berikut:

Tabel 2. Kategori Self-compassion

\begin{tabular}{lcc}
\hline Kategori Self-compassion & $\sum$ Subyek & \% \\
\hline Rendah & 10 & 2.5 \\
Sedang & 373 & 92.5 \\
Tinggi & 20 & 5.0 \\
Total & 403 & 100 \\
\hline
\end{tabular}

Pada tabel 2 mengenai sebaran kategori Self-compassion, hasil survei menunjukan bahwa sebanyak 92,56\% anak usia sekolah di Kota Bandung memiliki Self-compassion yang tergolong sedang, $4,96 \%$ tergolong rendah dan hanya $2,48 \%$ yang tergolong tinggi. Hal ini menunjukan bahwa sebagian besar anak usia sekolah di Kota Bandung dapat menerima dan menanggapi kegagalan yang dialami dengan tetap memperlakukan diri sendiri dengan baik, menerapkan rasa memahami pada diri sendiri dengan tidak memberikan penilaian negatif pada ketidakmampuan diri, dan memandang pengalaman negatif yang dialami sebagai pengalaman biasa.

Adapun hasil korelasi antara kecemasan sosial dan self-compassion dapat dilihat pada tabel 3 dibawah ini:

Tabel 3. Korelasi Self-compassion dan Kecemasan Sosial

\begin{tabular}{llc}
\hline & Correlation & \\
& & Kecemasan Sosial \\
\hline \multirow{3}{*}{ Self-compassion } & Pearson & $-.111^{*}$ \\
& Correlation & 0.025 \\
& Sig. (2 tailed) & 403 \\
$\mathrm{~N}$ & 0.05 level (2-tailed).
\end{tabular}

Hasil menunjukkan bahwa terdapat hubungan negatif yang signifikan antara self-compassion dengan kecemasan sosial, dengan $\mathrm{p}$ value $0.025(\mathrm{p}<0.05)$ dan nilai korelasi $-0,025$. Maka dari itu, hipotesis mengenai adanya korelasi antara kecemasan sosial dan self compasion dapat diterima. Adapun korelasi antara self-compassion dan kecemasan sosial pada siswa SD di Bandung tersebut bersifat negatif. Hasil ini menunjukkan bahwa semakin seorang individu peduli, memahami, dan memaklumi diri sendiri 
saat mengalami hal yang tidak menyenangkan, khususnya yang berkaitan dengan kegagalan ketika berinteraksi dengan orang lain atau menampilkan kemampuan diri, maka akan semakin rendah kemungkinan seseorang mengalami kecemasan sosial. Begitu juga sebaliknya, semakin seseorang tidak peduli atau menyalahkan, menghakimi diri sendiri saat mengalami kegagalan dalam berinteraksi dengan orang lain atau menunjukan penampilan atau performan tertentu, maka akan semakin rentan untuk mengalami kecemasan sosial. Hasil penelitian ini sejalan dengan penelitian sebelumnya yang menyatakan bahwa dibandingkan dengan individu yang memiliki self-compassion rendah, individu yang memiliki self-compassion tinggi memiliki kemampuan yang lebih baik dalam mengelola situasi negatif dan perasaan cemas setelah mengalami stressor (M. R. Leary, Tate, E. B., Adams, C.E., Allen, A. B., \& Hancock, J, 2007; Neff, et al., 2007).

Menurut Clark and Beck (2010 dalam Schwanen), penyebab individu dengan kecemasan sosial memiliki self-compassion yang rendah adalah adanya negative belief mengenai standar keberhasilan atau perilaku yang baik dan memiliki self-criticism yang tinggi. Mereka memiliki pemikiran bahwa mereka harus selalu tampil baik atau terlihat pintar dalam setiap penampilan mereka dan tidak boleh menunjukan kelemahan mereka pada orang lain. Keinginan untuk tidak boleh terlihat salah atau lemah di mata orang lain, membuat mereka tidak dapat memaklumi ketika diri mereka merasa bersalah dan mereka beranggapan bahwa orang lain akan menilai mereka secara negatif. Ketakutan untuk dinilai secara negatif membuat individu cemas kemudian menarik diri dari lingkungan sosialnya sehingga muncul perasaan terisolasi (Neff, 2011 dalam Schwanen).

Adapun hasil analisis statistik untuk melihat korelasi kecemasan sosial dengan aspek pembentuk self-compassion, yaitu (1) Self-warmth (gabungan dari aspek-aspek yang tergolong kutub positif, yaitu self-kindness, common humanity, dan mindfulness) dan (2) Self-coldness (gabungan dari aspek-aspek yang tergolong kutub negatif, yaitu self-judgement, over generalization, dan isolation), ditampilkan dalam tabel 4 sebagai berikut:

Tabel 4. Korelasi Aspek-aspek Self-compassion dengan Kecemasan Sosial

\begin{tabular}{lcc}
\hline \multicolumn{1}{c}{$\begin{array}{c}\text { Aspek-aspek } \\
\text { Self-compassion }\end{array}$} & \multicolumn{2}{c}{ Kecemasan Sosial } \\
\cline { 2 - 3 } & Pearson Corelation & $\begin{array}{c}\text { Sig (2- } \\
\text { tailed) }\end{array}$ \\
\hline Self-kindness & 0,048 & 0,455 \\
Self-judgement & $-.129^{*}$ & 0,045 \\
Common Humanity & 0,064 & 0,319 \\
Isolation & $-0,08$ & 0,211 \\
Over identification & $-.260^{* *}$ & 0 \\
Mindfulness & 0,027 & 0,675 \\
SELF-WARMTH & 0,059 & 0,356 \\
SELF-COLDNESS & $-.251^{* *}$ & 0 \\
\hline **. Correlation is significant at the 0.01 level (2-tailed). \\
*. Correlation is significant at the 0.05 level (2-tailed).
\end{tabular}

Berdasarkan Tabel 4, didapatkan bahwa aspek yang memiliki korelasi signifikan adalah selfcoldness yang merupakan skor total keseluruhan dari kutub negatif, yaitu self-judgement, overidentification, dan isolation $(r=0.251)$. Hal ini sesuai dengan pendapat dari Gilbert dalam Werner (2012) yang menyatakan bahwa perilaku mengkritik atau menilai diri negatif sangat berhubungan erat dengan kecemasan sosial. Self-coldness erat kaitannya dengan perilaku mengkritik diri sendiri. Adapun sub-aspek dari self-coldness yang juga berkorelasi signifikan dengan kecemasan sosial adalah self-judgement $(r=0.129)$ dan over-identification $(r=0.260)$. Korelasi yang signifikan pada aspek self-judgement dan over identification ini didukung oleh penelitian dari Van Dam (2011 dalam Werner, 2012) bahwa subscale self-judgement (bagian dari self-coldness) merupakan prediktor signifikan terhadap kemunculan gejala kecemasan dan depresi. 
Werner et al (2012) menjelaskan bagaimana self-compassion berhubungan dengan sekian faktor dan proses di dalamnya yang dikenal dengan kecemasan sosial. Proses yang pertama adalah ketakutan akan evaluasi negatif dari orang lain. Individu dengan kecemasan sosial cenderung memercayai bahwa setiap orang akan memperhatikan dan menilai mereka secara negatif. Ketakutan ini cenderung didasarkan pada pengalaman-pengalaman masa lalu dan keyakinan inti (Clark \& Wells, 1995). Ketakutan ini dapat memberikan dampak serius pada kemampuan individu dalam menghadapi situasi sehari-hari. Individu dengan self-compassion yang lebih tinggi menemukan cara yang lebih baik untuk menilai situasi negatif yang mereka alami dengan perspektif yang lebih positif dan mencapai evaluasi diri yang lebih positif. Hal ini mengindikasikan bahwa self-compassion adalah coping style yang penting ketika dihadapkan pada kejadian-kejadian interpersonal yang penting (Leary, Tate, Adams, Allen, \& Hancock, 2007).

Proses yang kedua adalah individu dengan kecemasan sosial melibatkan lebih banyak perhatian yang berfokus pada diri sendiri dimana mereka memonitor proses somatik, kognitif, dan internal dalam upaya menghilangkan risiko evaluasi sosial yang negatif (Spurr \& Stoppa, 2002). Proses ini mengurangi perhatian pada stimulus eksternal dan menghasilkan ketidaksambungan dengan lingkungan sehingga informasi berpusat dari sumber internal saja mengenai bagaimana dirinya berpenampilan di ruang umum (Rapee \& Heimberg, 1997). Hal ini akhirnya membawa pada renungan untuk mengkritisi diri sendiri yang kemudian dipersepsi sebagai kegagalan diri dan diperkuat dengan kekurangan untuk mengakses informasi eksternal sebagai jalan untuk konfirmasi informasi (Cox, Fleet, \& Stein, 2004; Padesky, 1997).

Pada akhirnya, kecemasan sosial ini dikarakteristikkan dengan sebuah kepercayaan akan strategi kognitif dan perilaku (McManus, Sacadura, \& Clark, 2008; Rao et al., 2007 dalam Gill et al, 2018) dan self-compassion dapat menjembatani hubungan ini, karena beberapa bukti mengemukakan bahwa meningkatkan self-compassion ketika dihadapkan kesulitan-kesulitan berkaitan dengan kebutuhan untuk terlibat dalam penghindaran kognitif. Misalnya, Neff, Kirkpatrcick, and Rude (2007) menemukan bahwa orang dengan self-compassion yang lebih tinggi mempunyai kecemasan akan evaluasi diri yang lebih rendah dibandingkan orang dengan self-compassion yang lebih tinggi ketika dihadapkan pada wawancara tiruan.

Proses tersebut menjadi penjelasan bagaimana self-compassion berkaitan dengan kecemasan sosial. Pada penelitian ini, dimensi dari self-compassion yang berhubungan erat dengan kecemasan sosial adalah self-judgement dan over identification. Meningkatnya perhatian atau fokus pada diri sendiri ketika berada pada situasi sosial membuat seseorang dengan kecemasan sosial yang tinggi berpikir berlebihan dalam mengidentifikasi (over-identification) pada pemikiran mereka, kondisi fisiologis, perilaku dan perasaan mereka sendiri (Bogels \& Mansell, 2004 dalam Schwanen). Hal ini kemudian membuat mereka menilai diri mereka secara negatif. Beberapa penelitian mengemukakan bahwa model teori kognitif saat ini menempatkan image diri yang negatif memainkan peran penting dalam mengembangkan dan mempertahankan kecemasan sosial (Clark and Wells, 1995; Hofmann, 2007; Rapee and Heimberg, 1997). Penelitian lain juga mengidentifikasikan bahwa ketika individu dengan kecemasan sosial memasuki situasi yang menakutkan baginya, mereka akan mengalihkan perhatian mereka untuk memonitor diri sendiri secara detail, mencatat sensasi internal dan tanda-tanda kecemasan, kemudian menggeneralisasikan gambaran diri yang negatif (Lee, Ahn dan Kwon, 2018).

\section{KESIMPULAN}

Berdasarkan penjelasan sebelumnya, dapat disimpulkan bahwa terdapat korelasi antara selfcompassion dan kecemasan sosial sesuai dengan hipotesis yang dibuat. Self-compassion memiliki korelasi negatif dengan kecemasan sosial walaupun korelasinya rendah. Sementara itu berdasarkan kelompok kutub positif dan negatif dari self-compassion yaitu self-warmth dan self-coldness, didapatkan hasil bahwa kutub negatif, yaitu self-coldness, memiliki korelasi positif dengan kecemasan sosial pada anak usia sekolah dasar di Kota Bandung. Adapun jika dilihat dari dimensi pembentuk self-compassion, dapat disimpulkan bahwa dimensi self-judgement dan over identification memiliki korelasi yang sangat signifikan dengan kecemasan sosial.

Untuk mendapatkan data yang lebih komprehensif dan khas pada anak usia sekolah dasar, perlu dilakukan penyempurnaan lebih lanjut terhadap penelitian ini. Pada penelitian berikutnya, akan lebih baik jika cakupan responden diperbanyak di seluruh wilayah Indonesia dan perlunya mendapatkan data 
kualitatif berupa situasi, contohnya pemikiran dan faktor-faktor penyebab dari kecemasan sosial pada anak.

\section{UCAPAN TERIMAKASIH}

Peneliti mengucapkan terimakasih kepada Universitas Padjadjaran karena penelitian ini terlaksana dengan dukungan dana dari Hibah Internal Universitas Padjadjaran. Selain itu, peneliti juga mengucapkan terimakasih kepada Airin Triwahyuni, M. Psi, psikolog dan Tobias Prawira Tumbuan, M.T atas diskusi analisis statistik yang dilakukan.

\section{DAFTAR PUSTAKA}

American Psychological Association. (2010). Publication manual of the American Psychological Association. Sixth edition. Washington D.C.: American Psychological Association

Barnard LK. (2011). Self-compassion: Conceptualizations, correlates, interventions. Review of General Psychology

Beucke, J. C., Sepulcre, J., Talukdar, T., Linnman, C., Zschenderlein, K., Endrass, T., \& Kathmann, N. (2013). Abnormally high degree connectivity of the orbitofrontal cortex in obsessive-compulsive disorder. JAMA psychiatry, 70(6), 619-629.

Bögels, S.M., \& Mansell, W. (2004). Attention processes in the maintenance and treatment of sosial phobia: hypervigilance, avoidance and self-focused attention. Clinical Psychology Review, 24, 827-856.

Bruce SE, Yonkers KA, Otto MW, Eisen JL, Weisberg RB, Pagano M, et al. (2005). Influence of psychiatric comorbidity on recovery and recurrence in generalized anxiety disorder, social phobia, and panic disorder: A 12-year prospective study. American Journal of Psychiatry. 162, (6), 1179-1187.

Clark, D.A., \& Beck, A.T. (2010). Cognitive therapy of anxiety disorders. Science and practice. New York: The Guilford Press.

Clark, D.M., \& Wells, A. (1995). A cognitive model of sosial phobia: Diagnosis, assessment and treatment. New York: The Guilford Press.

Cox BJ, Fleet C, \& Stein MB (2004). Self-criticism and sosial phobia in the US national comorbidity survey. Journal of Affective Disorders, 227-234.

Henderson, L. E., \& Zimbardo, P. (2010). Shyness, Social Anxiety, and Social Anxiety Disorder. https://doi.org/10.1016/B978-0-12-375096-9.00003-1

Hudson, J. L., Comer, J. S., \& Kendall, P. C. (2008). Parental responses to positive and negative emotions in anxious and nonanxious children. Journal of Clinical Child \& Adolescent Psychology, 37, (2), 303-313.

Iacono, G. (2018). A Call for Self-compassion in Social Work Education A Call for Self-compassion in Social Work Education Gio Iacono. https://doi.org/10.1080/08841233.2017.1377145

Gill, C., Watson, L., Williams, C., \& Chan, S. W. Y. (2018). Social anxiety and self-compassion in adolescents. 69, 163-165.

Gilbert P, McEwan K, Matos M, Rivis A. (2011) Fears of compassion: Development of three self-report measures. Psychology and Psychotherapy: Theory, Research and Practice.

Gilbert P, Procter S. (2006) Compassionate mind training for people with high shame and self-criticism: Overview and pilot study of a group therapy approach. Clinical Psychology \& Psychotherapy, 353-379.

Ginsburg, G. S., La Greca, A. M., \& Silverman, W. K. (1998). Social anxiety in children with anxiety disorders: Relation with social and emotional functioning. Journal of Abnormal Child Psychology, 26, (3), 175-185. https://doi.org/10.1023/A:1022668101048

Kashdan, Todd, \& Herber, James D. (2001). Social Anxiety Disorder in Childhood and Adolescence: Current Status and Future Directions. Clinical Child and Family Psychology Review, 4, (2) 
Leary, M. R., Tate, E. B., Adams, C. E., Allen, A. B., \& Hancock, J. (2007). Self-compassion and reactions to unpleasant self-relevant events: The implications of treating oneself kindly. Journal of Personality and Social Psychology, 92, 887-904.

Masia-Warner, C., Klein, R.G., Dent, H.C. et al. (20005). School-Based Intervention for Adolescents with Social Anxiety Disorder: Results of a Controlled Study. J Abnorm Child Psychol 33, 707722. https://doi.org/10.1007/s10802-005-7649-z

Neff KD and Germer CK. (2013). A pilot study and randomized controlled trial of the mindful selfcompassion program. Journal of Clinical Psychology, 28-44.

Neff KD. (2003); The development and validation of a scale to measure self-compassion. Self and Identity, 2, (3), 223-250. https://doi.org/10.1080/15298860309027

Neff, K. D., \& Vonk, R. (2009). Self-compassion versus global self-esteem: Two different ways of relating to oneself. Journal of Personality, 77, (1), 23-50.

Padesky, C. A. (1997). A more effective treatment focus for social phobia? International Cognitive Therapy Newsletter, 11, 1-3.

Rapee, R. M., \& Heimberg, R. G. (1997). A cognitive-behavioural model of anxiety in social phobia. Behaviour Research and Therapy, 35, (8), 741-756.

Sachs-Ericsson N, Verona E, Joiner T, \& Preacher KJ (2006). Parental verbal abuse and the mediating role of self-criticism in adult internalizing disorders. Journal of Affective Disorders, 93, (1-3), 7178.

Santrock, J. W. (2004). Live-Span Development: Perkembangan Masa Hidup. Jakarta: Erlangga

Schlenker, B. R., \& Leary, M. R. (1982). Social anxiety and self presentation: A conceptualization model. Psychological Bulletin, 92, 641-669

Spurr, J. M., \& Stopa, L. (2002). Self-focused attention in social phobia and social anxiety. Clinical Psychology Review, 22, (7), 947-975

Werner, Kelly H. 2012. Self-compassion and social anxiety disorder. Anxiety Stress Coping. 25, (5), 543558.

V, K. D. N., Kirkpatrick, K. L., \& Rude, S. S. (2007). Self-compassion and adaptive psychological functioning. 41, 139-154. 